\title{
ANALISIS KUNJUNGAN ULANG WISATAWAN NUSANTARA DENGAN MODEL KONSTRUK BERHIERARKI
}

\author{
Dwi Herayanthi W. ${ }^{\text {la }}$, I Komang Gde Sukarsa ${ }^{\text {bb }}$, Tjokorda Bagus Oka ${ }^{1 c}$, Eka N. Kencana ${ }^{2 \mathrm{~d} \S}$ \\ ${ }^{1}$ Jurusan Matematika, Fakultas MIPA - Universitas Udayana \\ ${ }^{2}$ Konsorsium Riset Pariwisata - Universitas Udayana

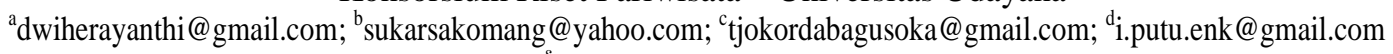 \\ ${ }^{\S}$ Corresponding Authors
}

\begin{abstract}
This research is aimed to analyze the effect of domestic tourists' satisfaction towards their intention to revisit destinations at Badung Regency, Province of Bali by using hierarchical construct modeling. Data from 75 local tourists were collected in July through December 2015 and were used to model this causal relationship. In our model, destination attributes, tourist's facilities, and destination accessibilities were positioned as the second-order constructs and proposed have effect on tourists' satisfaction. Futhermore, satisfaction - in turns - is proposed affects tourist intention to revisit. We found destination attributes significantly affect tourist satisfaction with its causal value is 0.410 and this satisfaction significantly affects their intention to revisit tourism destinations at Badung Regency with path value as much as 0.764 .
\end{abstract}

Keywords: hierarchical construct model, intention to revisit, tourist satisfaction

\section{PENDAHULUAN}

Structural Equation Modeling (SEM) atau pemodelan persamaan struktural adalah teknik statistika peubah ganda yang merupakan teknik kombinasi antara analisis regresi dengan analisis faktor. SEM dikenalkan oleh Joreskog dan Sorbom pada tahun 1973, digunakan untuk memeriksa model yang menjelaskan hubungan variabel laten dengan indikator-indikatornya (reflektif atau formatif) serta hubungan kausal antarvariabel laten pada model. Joreskog pada awalnya hanya mengembangkan teknik SEM berbasis kovarian (covariance-based SEM/CBSEM), tergolong ke dalam kelompok teknik statistika parametrik yang ketat pada pemenuhan asumsi distribusi galat.

Memperhatikan kekurangan dari CB-SEM yang ketat pada pemenuhan asumsi parametrik, sebagai alternatif dari kondisi tersebut maka muncul SEM berbasis varians atau berbasis komponen (component based SEM/PLS-SEM). Berbeda dengan CB-SEM yang ditujukan untuk mengkonfirmasi teori dan menjelaskan hubungan antara variabel laten, PLS-SEM lebih bersifat eksploratif. Spesifikasi model dalam PLS-SEM dapat dikategorikan menjadi dua model, yaitu model pengukuran yang menunjukkan hubungan antara indikator dengan variabel laten dan model struktural yang menunjukkan hubungan antar- variabel laten (Hair et al., 2013).

Seringkali teramati situasi permasalahan yang dimodelkan tidak cukup memadai bila hanya menggunakan variabel laten berdimensi tunggal (unidimensional latent variable), yang dicirikan oleh sebuah variabel laten langsung direfleksikan atau diformasikan oleh indikatorindikatornya. Saat variabel laten memiliki tingkat abstraksi yang lebih tinggi - dijelaskan oleh variabel-variabel laten lain - dan bersifat multidimensional, maka SEM yang dikembangkan menggunakan pendekatan konstruk berhierarki (hierarchical constructs model) (Wetzels et al., 2009).

Pada diskursus kepariwisataan, kepuasan dari wisatawan yang berkunjung ke sebuah 
destinasi merupakan syarat untuk menjaga keberlanjutan destinasi tersebut. Wisatawan yang merasa puas dengan pengalaman berwisatanya akan memiliki kecendrungan untuk kembali berkunjung (revisit) ke destinasi tersebut. Penelitian yang dilakukan Basiya dan Rozak (2012) yang bertujuan menganalisis faktor-faktor daya tarik objek wisata berdasarkan persepsi wisatawan serta pengaruhnya terhadap tingkat kepuasan dan niat kembali berwisata ke destinasi wisata di Provinsi Jawa Tengah. Kedua peneliti menggunakan analisis jalur pada model regresi berganda menunjukkan wisata alam, buatan, sosial, dan budaya memberikan pengaruh positif terhadap kepuasan wisatawan. Selain itu wisata alam, buatan, sosial, dan budaya terbukti memberikan pengaruh positif terhadap niat berwisata kembali. Menurut Fullerton dan Taylor dalam Dinamika Pariwisata (2012) purchase intention merupakan keinginan yang kuat untuk membeli kembali. Dalam hal ini kunjungan ulang wisatawan disebut behaviora intention to revisit.

Penelitian ini bertujuan untuk menganalisis hubungan kausal antara kepuasan wisatawan nusantara dengan niat untuk kembali berkunjung ke destinasi wisata di Kabupaten Badung dengan menggunakan SEM dengan konstruk berhierarki. Selain itu, juga ingin diketahui faktor-faktor yang berperan penting dalam menentukan tingkat kepuasan wisatawan nusantara yang berkunjung ke Kabupaten Badung, Provinsi Bali.

\section{METODE PENELITIAN}

A. Populasi dan Teknik Pengambilan Sampel.

Populasi pada penelitian ini adalah seluruh wisatawan nusantara yang mengunjungi destinasi wisata di Kabupaten Badung. Sampel dipilih menggunakan metode purposive sampling, dalam hal ini anggota sampel dipilih sesuai dengan tujuan penelitian (Sugiyono, 2003). Kuesioner sebagai instrumen pengumpul data dirancang. Setelah dievaluasi validitas setiap pernyataan dan reliabilitas masing-masing konstruk, kuesioner didistribusikan kepada 75 wisatawan nusantara (wisnus) yang terpilih sebagai anggota sampel. Adapun kriteria wisnus yang terpilih adalah: (a) berusia sekurang-kurangnya 18 tahun, (b) telah berwisata di salah satu destinasi wisata di Kabupaten Badung, (c) telah menginap di salah satu akomodasi wisata di Kabupaten Badung sekurang-kurangnya satu malam, dan (d) bersedia berpartisipasi secara sukarela pada penelitian ini. Distribusi kuesioner dilakukan pada bulan Desember - Januari 2016.

\section{B. Hipotesis Penelitian}

Evaluasi hubungan kausal antarvariabel laten utama pada model struktural berhierarki yang dikembangkan, dilakukan dengan membangun empat hipotesis penelitian sebagai berikut:

$\mathrm{H}_{1}$ : Atraksi wisata di destinasi berpengaruh terhadap kepuasan wisatawan nusantara;

$\mathrm{H}_{2}$ : Fasilitas wisata di destinasi berpengaruh terhadap kepuasan wisatawan nusantara;

$\mathrm{H}_{3}$ : Aksesibilitas di dalam/menuju destinasi berpengaruh terhadap kepuasan wisatawan nusantara; dan

$\mathrm{H}_{4}$ : Kepuasan wisatawan berpengaruh terhadap niat kembali berkunjung ke destinasi.

\section{Teknik Analisis Data.}

Tahapan penelitian ini mengikuti langkahlangkah berikut:

1. Merancang dilanjutkan dengan menguji kuesioner sebagai instrumen pengumpul data. Item pertanyaan dianggap valid apabila nilai koefisiennya di atas 0.30 (Churchill, 1979) dan variabel laten dianggap memiliki reliabilitas memadai bila nilai koefisien $\alpha$ di atas 0.70 (Nunnaly, 1975), meski pada risetriset eksploratif $\alpha$ di bawah 0.70 tetapi lebih besar dari 0.60 masih bisa diterima (Hair et al., 2013);

2. mengembangkan model persamaan struktural dengan melibatkan variabel laten berhierarki dan sekelompok indikator sesuai dengan teori yang melatarbelakanginya; 
3. memeriksa hubungan kausal antara indikator dengan variabel laten yang bersesuaian;

4. memeriksa hubungan kausal antarlaten dan goodness-of-fit (GoF). Meskipun PLS-SEM sebagai teknik non-parametrik dalam menganalisis model persamaan struktural tidak memiliki ukuran kelayakan model (goodness-of-fit/GoF). dari model seperti halnya pada CB-SEM, Tenenhaus et al. (2005) mengusulkan formula yang bisa digunakan untuk memprediksi kualitas model yang dibangun, yaitu:

$$
\widetilde{\mathrm{GoF}}=\sqrt{\overline{A V E} \cdot \overline{R^{2}}}
$$

Pada persamaan (1), $\overline{A V E}$ dan $\overline{R^{2}}$ adalah rataan terbobot dengan bobot adalah jumlah indikator dari masing-masing laten endogen pada model. Dengan nilai $\mathrm{R}^{2}>0.50$ sebagai batas untuk menyatakan variabel laten memiliki validitas konvergensi yang baik (Peng \& Lai, 2012) yang menunjukkan indikator-indikator reflektifnya saling berinterelasi satu dengan lainnya (Brown, 2006, p.216); dan
5. menginterpretasikan hasil analisis PLS-SEM serta mengevaluasi hipotesis yang dibangun.

\section{HASIL DAN PEMBAHASAN}

\section{A. Profil Responden Penelitian}

Hasil analisis deskriptif pada karakteristik wisnus yang terpilih sebagai sampel penelitian menunjukkan responden berjenis kelamin lakilaki memiliki proporsi 61.3 persen dan dominan berada pada rentang umur 20-25 tahun sebesar 41.3 persen. Tujuan wisnus berkunjung destinasi wisata di Kabupaten Badung didominasi oleh keinginan berlibur dengan proporsi sebesar 72.0 persen, dan hampir setengahnya merencanakan menginap selama 4-6 hari.

\section{B. Uji Kelayakan Kuesioner}

Kelayakan dari kuesioner pada penelitian ini dilakukan dengan memeriksa nilai koefisien alpha Cronbach dan nilai korelasi antara item yang diperiksa dengan item-item lainnya pada variabel laten yang sama.

Tabel 1. Hasil Uji Kelayakan Kuesioner Penelitian dengan SPSS 20

\begin{tabular}{|c|c|c|}
\hline $\begin{array}{l}\text { Variabel } \\
\text { Laten }\end{array}$ & Item & $\begin{array}{r}\text { Kore- } \\
\text { lasi }\end{array}$ \\
\hline \multirow{4}{*}{$\begin{array}{l}\text { Atraksi } \\
\text { Alam } \\
\alpha=0.757\end{array}$} & X1 Panorama alam & 0.626 \\
\hline & X2 $\quad$ Udara & 0.548 \\
\hline & X3 Hutan & 0.588 \\
\hline & X4 Flora dan fauna & 0.479 \\
\hline \multirow{3}{*}{$\begin{array}{l}\text { Atraksi } \\
\text { Buatan } \\
\alpha=\underline{0.566}\end{array}$} & X5 Arsitektur & 0.320 \\
\hline & X6 Museum & 0.380 \\
\hline & X7 Monumen & 0.449 \\
\hline \multirow{3}{*}{$\begin{array}{l}\text { Atraksi } \\
\text { Sosial } \\
\alpha=0.725\end{array}$} & $\begin{array}{l}\text { X8 Tempat tinggal dan } \\
\text { bahasa }\end{array}$ & 0.560 \\
\hline & X9 Gaya hidup & 0.579 \\
\hline & $\begin{array}{l}\text { X10 Keramahan dan } \\
\text { kesopanan }\end{array}$ & 0.503 \\
\hline \multirow{3}{*}{$\begin{array}{l}\text { Atraksi } \\
\text { Budaya } \\
\alpha=0.662\end{array}$} & X11 Hiburan & 0.399 \\
\hline & X12 Cerita rakyat/legenda & 0.446 \\
\hline & $\begin{array}{l}\text { X13 Festival budaya dan } \\
\text { ritual agama }\end{array}$ & 0.592 \\
\hline \multirow{3}{*}{$\begin{array}{l}\text { Fasilitas } \\
\text { Pokok } \\
\alpha=0.693\end{array}$} & X14 Fasilitas akomodasi & 0.608 \\
\hline & X15 Biro perjalanan & 0.501 \\
\hline & X16 Fasilitas kuliner & 0.689 \\
\hline \multirow{3}{*}{$\begin{array}{l}\text { Fasilitas } \\
\text { Pelengkap } \\
\alpha=\underline{0.565}\end{array}$} & X17 Fasilitas olahraga & 0.476 \\
\hline & $\begin{array}{l}\text { X18 Sarana piknik dan } \\
\text { perkemahan }\end{array}$ & 0.536 \\
\hline & X19 Sarana rekreasi & 0.386 \\
\hline
\end{tabular}

\begin{tabular}{|c|c|c|}
\hline $\begin{array}{l}\text { Variabel } \\
\text { Laten }\end{array}$ & Item & $\begin{array}{r}\text { Kore- } \\
\text { lasi }\end{array}$ \\
\hline \multirow{3}{*}{$\begin{array}{l}\text { Fasilitas } \\
\text { Penunjang } \\
\alpha=0.670\end{array}$} & X20 Fasilitas hiburan malam & 0.729 \\
\hline & X21 Salon dan spa & 0.410 \\
\hline & X22 Fasilitas berbelanja & 0.574 \\
\hline \multirow{2}{*}{$\begin{array}{l}\text { Informasi } \\
\alpha=0.709\end{array}$} & X23 Panduan berwisata & 0.550 \\
\hline & X24 Akses internet & 0.550 \\
\hline \multirow{3}{*}{$\begin{array}{l}\text { Akses Jalan } \\
\alpha=\underline{0.541}\end{array}$} & X25 Kondisi jalan \& trotoar & 0.249 \\
\hline & X26 Kelancaran lalu lintas & 0.327 \\
\hline & X27 Penggunaan troli barang & 0.503 \\
\hline \multirow{2}{*}{$\begin{array}{l}\text { Parkir dan } \\
\text { Terminal } \\
\alpha=0.612\end{array}$} & X28 Fasilitas parkir & 0.450 \\
\hline & $\begin{array}{l}\text { X29 Lokasi terminal dekat } \\
\text { dengan destinasi tujuan }\end{array}$ & 0.450 \\
\hline \multirow{5}{*}{$\begin{array}{l}\text { Tingkat } \\
\text { Kepuasan } \\
\alpha=0.809\end{array}$} & W1 Senang berkunjung & 0.524 \\
\hline & W2 Persepsi > ekspektasi & 0.613 \\
\hline & W3 Kemenarikan destinasi & 0.642 \\
\hline & W4 Kebersihan destinasi & 0.665 \\
\hline & W5 Kenyamanan berkunjung & 0.603 \\
\hline \multirow{4}{*}{$\begin{array}{l}\text { Niat untuk } \\
\text { Revisit } \\
\alpha=0.894\end{array}$} & Y1 Destinasi favorit & 0.752 \\
\hline & Y2 Kembali berkunjung & 0.745 \\
\hline & $\begin{array}{ll}\text { Y3 Niat merekomendasikan } \\
\text { destinasi }\end{array}$ & 0.804 \\
\hline & Y4 Niat menginformasikan & 0.767 \\
\hline
\end{tabular}


Pada Tabel 1 terlihat 3 dari 12 variabel laten pada model memiliki nilai koefisien alpha yang lebih kecil dari nilai batas 0.60, menunjukkan bahwa ketiga variabel laten tersebut tidak reliabel. Variabel laten akses jalan selain memiliki koefisien alpha terkecil juga memiliki indikator reflektif dengan koefisien korelasi di bawah nilai batas 0.3 yaitu item X25 memiliki koefisien korelasi hanya sebesar 0.249, nilai tersebut menunjukkan bahwa item X25 tidak valid. Memerhatikan hal ini, maka X25 dieliminasi dari model, yang menyebabkan nilai koefisien alpha untuk laten akses jalan meningkat menjadi 0.582 . Dengan demikian, model operasional penelitian berubah seperti terlihat pada Gambar 1.

PLS-SEM seperti halnya dengan CB-SEM, disusun oleh dua sub-model yaitu outer model dan inner model. Memperhatikan hal ini, maka analisis model persamaan struktural yang dibuat dilakukan dengan memperhatikan hasil analisis pada masing-masing sub-model.

\section{Hasil Analisis Outer Model}

Analisis pada outer model atau juga disebut measurement model dilakukan untuk memeriksa hubungan antara variabel laten dengan indikator-indikatornya. Memperhatikan hal ini, maka pada model SEM berhirarki, analisis ditujukan hanya pada variabel laten orde satu, sebuah variabel laten yang direfleksikan atau diformasikan secara langsung oleh indikator-indikatornya, yang juga disebut manifest variable. Tabel 2 menunjukkan nilai outer loading dan $p$-value dari setiap item reflektif pada variabel laten yang bersesuaian.

Mencermati hasil analisis pada outer model penelitian, maka beberapa fakta terkait dengan persepsi wisatawan nusantara terhadap kepuasan dan niat untuk kembali berkunjung ke destinasi dapat dirinci sebagai berikut:

1. Atraksi wisata di Kabupaten Badung yang terefleksikan dalam empat variabel laten orde satu dipersepsikan lebih dominan pada atraksi wisata buatan, disusul oleh atraksi sosial. Indikator yang dipersepsikan paling positif pada atraksi buatan dan atraksi sosial adalah monumen (salah satunya patung Garuda Wisnu Kencana) dan kebiasaan hidup dari penduduk (pedesaan) di Kabupaten Badung;

2. Restoran serta tempat wisata kuliner lainnya, sarana perkemahan, dan wisata malam di Kabupaten Badung merupakan tiga indikator yang dipersepsikan terendah oleh wisatawan nusantara pada variabel-variabel laten fasilitas pokok, pelengkap, dan fasilitas penunjang sebagai refleksi fasilitas wisata;

3. Faktor aksesibilitas wisata di Kabupaten Badung dominan terefleksikan pada laten kemudahan akses informasi. Ketersediaan panduan wisata dalam bentuk peta, brosur, dan sejenisnya dipersepsikan secara positif oleh wisatawan nusantara yang berkunjung;

4. Kepuasan wisatawan nusantara dominan terefleksikan pada kemenarikan destinasi di daerah ini. 


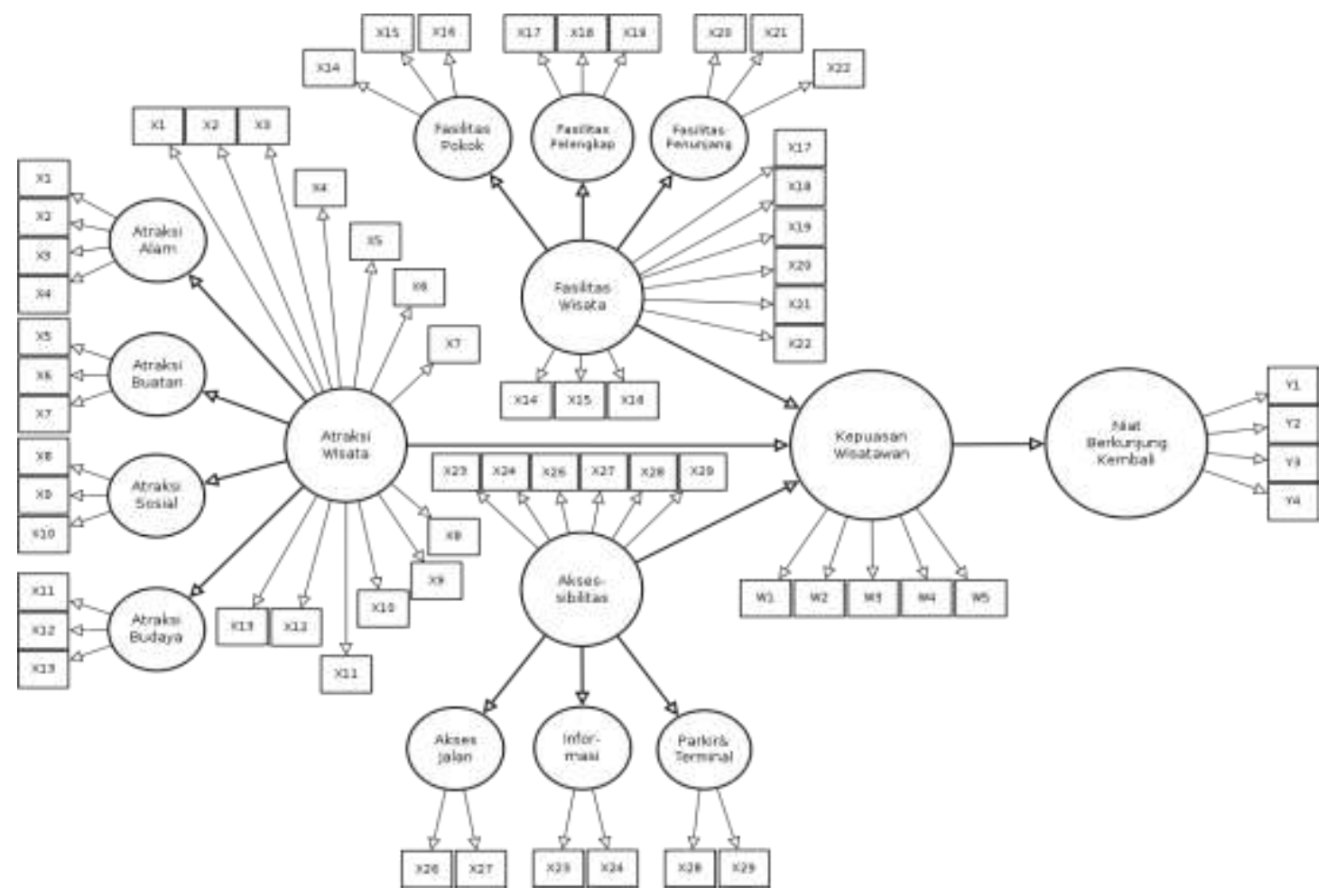

Gambar 1. Model Operasional Penelitian

Tabel 2. Hasil Analisis Outer Model dari Variabel Laten Orde Satu

\begin{tabular}{|c|c|c|c|c|c|}
\hline Variabel Laten & AVE & $\begin{array}{r}\Sigma \\
\text { Item }\end{array}$ & Item $^{\S}$ & $\begin{array}{r}\text { Outer } \\
\text { Loading }\end{array}$ & $\begin{array}{r}p- \\
\text { Value }\end{array}$ \\
\hline \multirow{4}{*}{$\begin{array}{l}\text { Atraksi Alam } \\
\mathrm{R}^{2}=0.646\end{array}$} & \multirow{4}{*}{0.578} & \multirow{4}{*}{4} & X3 & 0.812 & 0.000 \\
\hline & & & $\mathrm{X} 4$ & 0.768 & 0.000 \\
\hline & & & $\mathrm{X} 1$ & 0.764 & 0.000 \\
\hline & & & $\mathrm{X} 2$ & 0.691 & 0.000 \\
\hline \multirow{3}{*}{$\begin{array}{l}\text { Atraksi Buatan } \\
\mathrm{R}^{2}=0.767\end{array}$} & \multirow{3}{*}{0.541} & \multirow{3}{*}{3} & $\mathrm{X} 7$ & 0.767 & 0.000 \\
\hline & & & X6 & 0.739 & 0.000 \\
\hline & & & $\mathrm{X} 5$ & 0.699 & 0.000 \\
\hline \multirow{3}{*}{$\begin{array}{l}\text { Atraksi Sosial } \\
\mathrm{R}^{2}=0.758\end{array}$} & \multirow{3}{*}{0.645} & \multirow{3}{*}{3} & X9 & 0.821 & 0.000 \\
\hline & & & $\mathrm{X} 8$ & 0.809 & 0.000 \\
\hline & & & $\mathrm{X} 10$ & 0.779 & 0.000 \\
\hline \multirow{3}{*}{$\begin{array}{l}\text { Atraksi Budaya } \\
\mathrm{R}^{2}=0.707\end{array}$} & \multirow{3}{*}{0.601} & \multirow{3}{*}{3} & $\mathrm{X} 13$ & 0.829 & 0.000 \\
\hline & & & $\mathrm{X} 11$ & 0.773 & 0.000 \\
\hline & & & $\mathrm{X} 12$ & 0.720 & 0.000 \\
\hline \multirow{3}{*}{$\begin{array}{l}\text { Fasilitas Pokok } \\
\mathrm{R}^{2}=0.803\end{array}$} & \multirow{3}{*}{0.623} & \multirow{3}{*}{3} & $\mathrm{X} 15$ & 0.840 & 0.000 \\
\hline & & & $\mathrm{X} 14$ & 0.775 & 0.000 \\
\hline & & & $\mathrm{X} 16$ & 0.751 & 0.000 \\
\hline \multirow{3}{*}{$\begin{array}{l}\text { Fasilitas } \\
\text { Pelengkap } \\
\mathrm{R}^{2}=0.672\end{array}$} & \multirow{3}{*}{0.533} & \multirow{3}{*}{3} & $\mathrm{X} 17$ & 0.824 & 0.000 \\
\hline & & & $\mathrm{X} 19$ & 0.764 & 0.000 \\
\hline & & & $\mathrm{X} 18$ & 0.376 & 0.029 \\
\hline
\end{tabular}

\begin{tabular}{|c|c|c|c|c|c|}
\hline Variabel Laten & AVE & $\begin{array}{r}\Sigma \\
\text { Item }\end{array}$ & Item & $\begin{array}{r}\text { Outer } \\
\text { Loading }\end{array}$ & $\begin{array}{r}p- \\
\text { Value }\end{array}$ \\
\hline \multirow{3}{*}{$\begin{array}{l}\text { Fasilitas } \\
\text { Penunjang } \\
\mathrm{R}^{2}=0.679\end{array}$} & \multirow{3}{*}{0.615} & \multirow{3}{*}{3} & $\mathrm{X} 21$ & 0.865 & 0.000 \\
\hline & & & $\mathrm{X} 22$ & 0.788 & 0.000 \\
\hline & & & $\mathrm{X} 20$ & 0.689 & 0.012 \\
\hline \multirow{2}{*}{$\begin{array}{l}\text { Informasi } \\
R^{2}=0.583\end{array}$} & \multirow{2}{*}{0.774} & \multirow{2}{*}{2} & $\mathrm{X} 23$ & 0.898 & 0.000 \\
\hline & & & $\mathrm{X} 24$ & 0.861 & 0.000 \\
\hline \multirow[b]{2}{*}{$\begin{array}{l}\text { Akses Jalan } \\
\mathrm{R}^{2}=0.601\end{array}$} & \multirow[b]{2}{*}{0.703} & \multirow[b]{2}{*}{2} & $\mathrm{X} 27$ & 0.877 & 0.001 \\
\hline & & & $\mathrm{X} 26$ & 0.798 & 0.000 \\
\hline \multirow{2}{*}{$\begin{array}{l}\text { Parkir \& Terminal } \\
\mathrm{R}^{2}=0.658\end{array}$} & \multirow{2}{*}{0.720} & \multirow{2}{*}{2} & $\mathrm{X} 28$ & 0.901 & 0.000 \\
\hline & & & X29 & 0.793 & 0.000 \\
\hline \multirow{5}{*}{$\begin{array}{l}\text { Kepuasan } \\
\text { Wisatawan } \\
\mathrm{R}^{2}=0.466\end{array}$} & \multirow{5}{*}{0.582} & \multirow{5}{*}{5} & W3 & 0.802 & 0.000 \\
\hline & & & W4 & 0.788 & 0.000 \\
\hline & & & W2 & 0.773 & 0.000 \\
\hline & & & W5 & 0.740 & 0.000 \\
\hline & & & W1 & 0.706 & 0.000 \\
\hline \multirow{4}{*}{$\begin{array}{l}\text { Niat untuk } \\
\text { Revisit } \\
\mathrm{R}^{2}=0.584\end{array}$} & \multirow{4}{*}{0.760} & \multirow{4}{*}{4} & Y3 & 0.900 & 0.000 \\
\hline & & & Y1 & 0.885 & 0.000 \\
\hline & & & $\mathrm{Y} 2$ & 0.885 & 0.000 \\
\hline & & & $\mathrm{Y} 2$ & 0.847 & 0.000 \\
\hline
\end{tabular}

Tabel 2 menunjukkan, kecuali pada kepuasan wisatawan, seluruh variabel laten endogen orde satu pada model memiliki nilai 0.5 menunjukkan indikator-indikator reflektifnya saling berinterelasi satu dengan lainnya. Pada laten kepuasan wisatawan,

meskipun nilai $\mathrm{R}^{2}$ sedikit lebih kecil dari 0.50 , mempertimbangkan seluruh indikator memiliki factor loading yang nyata, maka laten ini juga dikategorikan sebagai laten yang memiliki kualitas pengukuran yang baik. Mempertimbangkan hasil analisis pada model 
pengukuran, maka analisis model struktural (inner model) yang menyatakan hubungan kausal antarvariabel laten dapat dilakukan.

\section{Hasil Analisis Inner Model}

Memperhatikan PLS-SEM merupakan teknik statistika peubah ganda non-parametrik, maka pendugaan parameter model dilakukan melalui teknik bootstrap yang pada program SmartPLS dilakukan dengan mengatur jumlah sub-sample sebesar 500. Gambar 2 menunjukkan koefisien jalur dari masingmasing pengaruh langsung variabel laten eksogen terhadap laten endogen pada inner model.

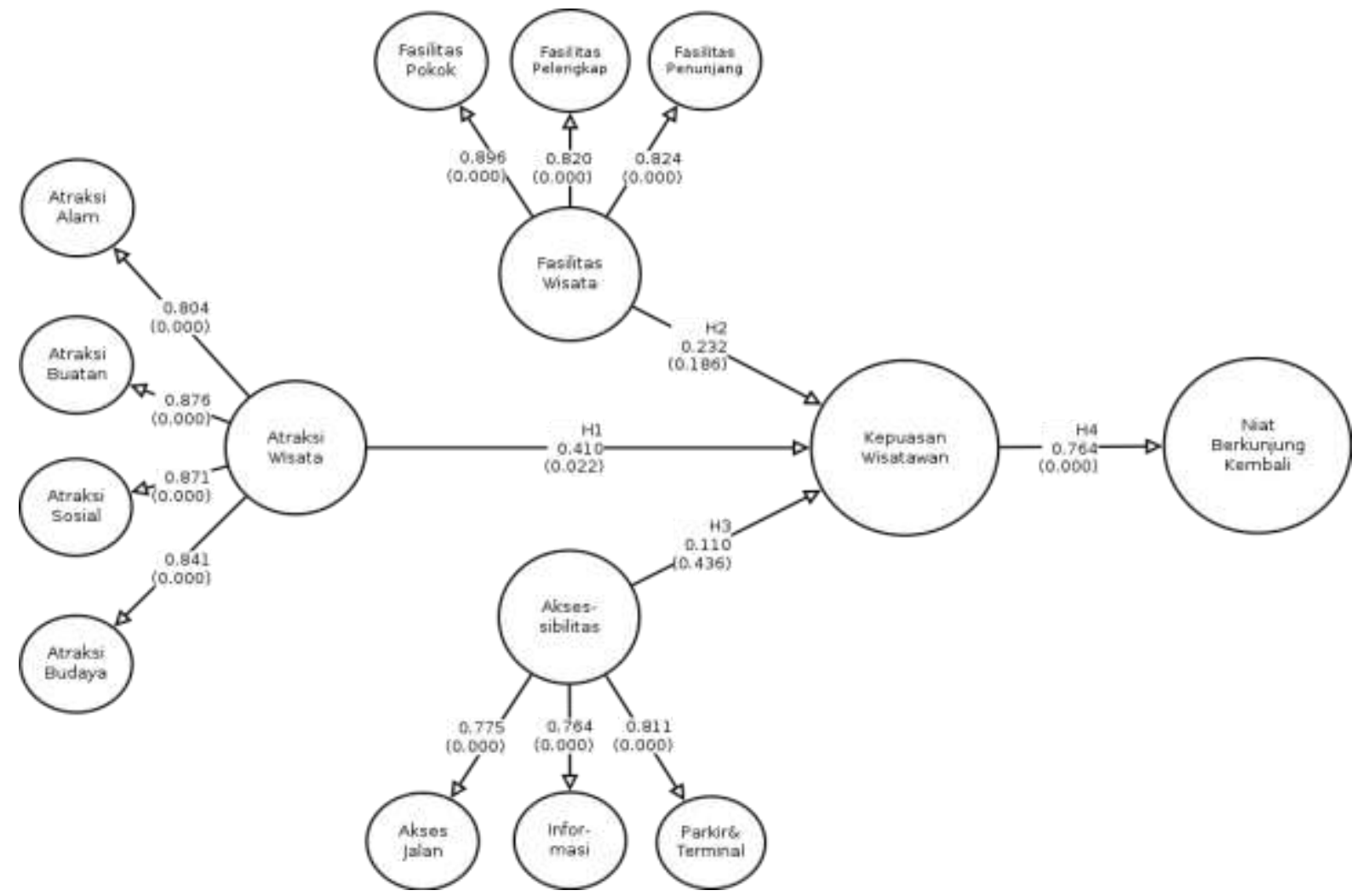

Gambar 2. Hasil Analisis pada Inner Model

Gambar 2 memperlihatkan variabel laten atraksi wisata sebagai laten multidimensional terefleksikan secara nyata pada keempat variabel laten orde satu yang bersifat unidimensi. Atraksi wisata dominan terefleksikan pada atraksi wisata buatan dengan koefisien jalur sebesar 0.876 dan paling kecil direfleksikan pada atraksi wisata alam dengan koefisien jalur sebesar 0.804 .

Pada variabel laten fasilitas wisata, meskipun seluruh variabel laten orde satu direfleksikan secara nyata, terbukti bahwa wisatawan nusantara lebih mengedepankan fasilitas inti wisata sebagai cerminan fasilitas wisata di Kabupaten Badung. Selain itu, pada laten multidimensi aksesibilitas, kondisi parkir dan terminal yang memudahkan wisatawan beraktivitas dipersepsikan tertinggi dengan koefisien jalur sebesar 0.811 .

Meski demikian, dari tiga laten multidimensi ini, hanya variabel laten atraksi wisata yang memiliki pengaruh signifikan terhadap kepuasan wisatawan nusantara yang berkunjung dengan nilai koefisien jalur sebesar 0.410. Dua variabel lainnya tidak terbukti berpengaruh signifikan terhadap tingkat kepuasan wisatawan nusantara yang berkunjung ke destinasi wisata di Kabupaten Badung. Pada hubungan kausal antara kepuasan wisatawan terhadap niat kembali berkunjung, terbukti 
wisatawan nusantara yang merasa puas dengan kunjungan wisatanya berpengaruh secara positif dan nyata terhadap niat untuk berkunjung kembali dengan nilai koefisien jalur sebesar 0.764 .

\section{E. Kualitas Model dan Hasil Evaluasi Hipotesis}

Melalui persamaan (1), kualitas model SEM pada penelitian ini diperoleh $\widetilde{\mathrm{GoF}}$ sebesar 0.641 , sebuah ukuran yang cukup baik untuk menilai kualitas model.

Mencermati bahwa model struktural untuk mengevaluasi pengaruh kepuasan wisatawan nusantara terhadap niatnya kembali berkunjung ke destinasi wisata di Kabupaten Badung layak digunakan, maka evaluasi pada hipotesis yang dibangun bisa dilakukan. Terdapat dua hipotesis $\left(\mathrm{H}_{1}\right.$ dan $\left.\mathrm{H}_{4}\right)$ yang tidak bisa ditolak pada taraf uji 5 persen, dan dua hipotesis yang ditolak $\left(\mathrm{H}_{2}\right.$ dan $\left.\mathrm{H}_{3}\right)$ pada taraf uji 5 persen. Atraksi wisata terbukti berpengaruh terhadap kepuasan wisatawan nusantara $\left(\mathrm{H}_{1}\right)$, yang selanjutnya memengaruhi niatnya untuk kembali berkunjung $\left(\mathrm{H}_{4}\right)$. Fasilitas wisata dan aksesibilitas wisata di Kabupaten Badung tidak terbukti berpengaruh secara nyata pada kepuasan wisatawan nusantara.

Penelitian ini juga mengonfirmasi teori dari Fullerton dan Taylor yang menyebutkan adanya pengaruh positif dari kepuasan wisatawan terdapat niat untuk kembali berkunjung. Hasil penelitian menyimpulkan wisatawan nusantara yang terpuaskan dengan kunjungannya memiliki pengaruh positif dan nyata terhadap niat untuk berkunjung kembali.

\section{SIMPULAN DAN REKOMENDASI}

Sebagai simpulan dari penelitian ini adalah atraksi wisata di Kabupaten Badung yang terefleksikan ke dalam empat jenis atraksi berpengaruh secara nyata kepada kepuasan wisatawan nusantara yang mengunjungi berbagai destinasi di daerah ini. Fasilitas dan aksesibilitas wisata ternyata tidak memberikan kontribusi signifikan pada penyusunan kepuasan wisatawan nusantara yang berkunjung.

Disarankan kepada pihak-pihak yang berkepentingan di bidang kepariwisataan di Kabupaten Badung untuk membenahi dan meningkatkan kualitas destinasi wisata wisata di daerah ini, khususnya pada fasilitas wisata dan aksesibilitas menuju dan di dalam destinasi yang belum menunjukkan efek nyata pada kepuasan wisatawan nusantara yang berkunjung.

\section{DAFTAR PUSTAKA}

Basiya \& Rosak, H.A., 2012. Kualitas Daya Tarik Wisata, Kepuasan dan Niat Kunjungan Kembali Wisatawan Mancanegara di Jawa Tengah. Dinamika Kepariwisataan, XI(2), pp.1-12.

Brown, T.A., 2006. Confirmatory Factor Analysis for Applied Research. New York, USA: The Guilford Press.

Churchill, G.A., 1979. A Paradigm for Developing Better Measures of Marketing Constructs. Journal of Marketing Research, 16(1), pp.64-73.

Hair, J.F., Hult, G.T.M., Ringle, C.M. \& Sarstedt, M., 2013. A Primer on Partial Least Square Structural Equation Modeling. New York: SAGE.

Nunnaly, J.C., 1975. Psychometric Theory. 25 Years Ago and Now. Educational Researcher, 4(10), pp.7-14;19-21.

Peng, D.X. \& Lai, F., 2012. Using partial least squares in operations management research: A practical guideline and summary of past research. Journal of Operation Management, 30, pp.467-80.

Sugiyono, 2003. Metode Penelitian Bisnis. Bandung: Pusat Bahasa Depdikas.

Tenenhaus, M., Vinzi, V.E., Chatelin, Y.-M. \& Lauro, C., 2005. PLS path modeling. Computational Statistics \& Data Analysis, 48, pp.159-205.

Wetzels, M., Odekerken-Schroder, G. \& Oppen, C.v., 2009. Using PLS Path Modeling for Assesing Hierarchical Construct Models. MIS Quaterly, 33(1), pp.177-95. 